\title{
PLAG1 Gene
}

National Cancer Institute

\section{Source}

National Cancer Institute. PLAG1 Gene. NCI Thesaurus. Code C71423.

This gene is involved in cellular proliferation. 